\section{SOI: $1.1 / \mathrm{TAS} \quad$ DOI: $10.15863 / \mathrm{TAS}$ International Scientific Journal Theoretical \& Applied Science}

\author{
p-ISSN: 2308-4944 (print) e-ISSN: 2409-0085 (online) \\ Year: $2016 \quad$ Issue: 3 Volume: 35 \\ Published: $30.03 .2016 \quad \underline{\text { http://T-Science.org }}$
}

Zarifa Valad gyzy Damirova PhD in Physics and Mathematics, Associate Professor of the Department of Teaching Methods of Physics,

Sumgait State University zarifadamirova@hotmail.com

SECTION 21. Pedagogy. Psychology. Innovations in the field of education.

\title{
THE ROLE OF ICT IN THE SCHOOL COURSE OF PHYSICS
}

\begin{abstract}
The article is devoted to some problems of the education system. It is about the application of Information and Communication Technologies in the education system.

Statement of the problem in the general form and its connection with the important scientific and practical tasks. In the conditions of information society the modern teacher must not only possess professional knowledge and skills well, but also be able to adapt himself to the rapid processes both in the professional and public spheres of life, and use the means of new information technologies, be competent, able to participate actively in the public life, self-realize and constantly develop himself. Therefore, the problem of professional development of the teachers becomes very topical, and the issue arises what namely and how it is necessary to change on the enhancement training courses, in order that a modern teacher meeting the requirements of time could provide the high level knowledge acquisition by the pupils based on the modern approaches and methods of teaching.

Moreover, it should be noted that in the modern world the informatization of education is one of the priority directions of modernizing the native system of education, human training to life in the information society on the assumption of global transformation. This puts the certain range of requirements to the teacher: he must be able to work with computer equipment, own the certain information-computer technologies.

As practice shows, in the process of distance learning in most cases teachers are limited with placing of lecture courses in electronic form and with the implementation of automated testing system in the control stage. This article discusses the methods of organization of independent work in terms of distance learning of physics.

Key words: education, information, technology, teaching, distance learning, independent activity, long-term different level tasks, working abstract, component, structural element, integrative model of teaching process.

Language: English

Citation: Damirova ZV (2016) THE ROLE OF ICT IN THE SCHOOL COURSE OF PHYSICS. ISJ Theoretical \& Applied Science, 03 (35): 84-92.

Soi: http://s-o-i.org/1.1/TAS-03-35-16 Doi: crossef http://dx.doi.org/10.15863/TAS.2016.03.35.16
\end{abstract}

Modern education develops in the context of rapid development of information technologies. Countries, members of the European Union declared as the priority of the European education the accession of all educational systems of EU countries to the Lisbon Declaration, which proclaims the general trend of informatization of education in Europe. As the European Commissioner for Education and Culture of the European Commission Viviane Reding stated, "one of the priorities of European cooperation is the use of multimedia and Internet technologies in the context of improving the quality of education" [1]. V.Reding emphasizes the need to equip if not all classes, all schools with the latest computers and technologies in order the teachers could use these technologies to improve the working methods. This is also necessary to ensure that students could expand their own horizons of knowledge through the use of multimedia in the socalled necessary critical perspective.

It should be noted that information and communication technologies are part of the common educational package in most European countries. At primary level of education, only seven countries had not included the ICT in the educational package (Italy, Bulgaria, Czech Republic, Latvia, Lithuania, Hungary and Slovakia) [1]. In other countries, ICT is included in the basic academic curriculum. The ICT content is implemented according to two different approaches: the first - ICT can be taught as a separate subject, the other - it can be used to teach other subjects.

The second approach, which is dominant in European countries, should be noted in particular. It lies in the fact that ICT is used in teaching a variety of subjects at primary school level [2]. Sometimes in 
one country both types of ICT are adopted. For example, in Greece, since October 2002, the ICT is one of the compulsory/universal subjects in day primary school. In France also, since 2002, gradually began to be implemented the ICT in the content of compulsory education in primary school, but not as a separate subject, but as a means of teaching for other academic disciplines.

Two approaches are used in the UK, where information technologies may be presented as a separate subject, and to be integrated through the socalled cross-software combinations. Whereas in Hungary, for example, the basic academic curriculum provides preparation for life in the information society, but ICT training is not compulsory. In Romania, ICT is a matter of choice.

These different approaches reflect the traditions and educational policies of various countries in the implementation of ICT technologies and training as well.

Teacher's training is also an important area for the application of computer technologies in the context of improving the quality of education in the developed countries of Europe and the world. The experience of countries where ICT is presented as a separate subject or a means for teaching of other subjects can be considered interesting; special assistants that accompany computer maintenance of the educational process often help teachers, which is a fairly common practice in the school system. The above mentioned specialists (assistants) are with higher university-level pedagogical education. According to the UNESCO's world report [2] (the world report of UNESCO on communication and information in 1999-2000) the number of applied means and networks of digital information technology in education have increased in the world. For the period of 1998 most of the teachers were not trained in ICT; they could use them quite limited in the learning process, schools were not sufficiently equipped with computer facilities, even in the most developed countries. Today for the pedagogical community of the world there is a problem of teachers' training, able to work under the conditions of the rapid progress of information and communication technologies, though such technologies as movies, video films, TV and radio continue to play a major role in the formation of all countries.

The effectiveness of the ICT use is widely studied by scientists around the world. It should be noted that the transference of knowledge through ICT causes impact on school results of students. So, in 2000 in Helsinki (Finland) was carried out research of innovative teaching methods in the framework of a variety of disciplines, which were based on the application of the computer. According to www2.ncsu.edu/oit/nsdsplit.htm source [3], the tasks borne through the so-called "technical channel", such as television, radio, computer network is an effective teaching tool. The use of computers also affects students' interest in learning.

The application of the so-called "constructivist" teaching encourages students to learn in an informative environment, which creates own idea about it, and generates the appropriate habits and competence. The use of various forms of distance learning in the education system also significantly affects the rate and success of mastering the material, finding habits and competencies required for ICT.

Let's consider in detail that foreign educational institutions offer for the implementation of computer technology in school education. For example, the Canadian Institute of Ontario Education Research [4] (Ontario Institute for Studies in Education csile.oise.utoronto.ca/intro.html) developed the socalled learning environment with computer support (Computer Supported Intentional Learning Environments), that is a network system, making it possible to carry out school education and oral test. This system allows establishing cooperation between the students through working with a variety of information sources, to carry out the union of ideas and collective authorship, provides an opportunity to use the results of other students for the purpose of gaining knowledge. The main feature of the teaching environment, developed by Canadian teachers, is the existence of the database, to which students can add texts, graphics, their comments regarding the work of other students, etc. In this context, in many countries in the computer networks of educational institutions are created electronic libraries that can contain textbooks, periodicals, illustrations, diagrams, graphics, three-dimensional models, animations, reference materials, audio files, movies and videos, and others.

In the World Wide Web, there are many Web pages that contain educational information, starting from curricula and programs, teaching materials and materials for extracurricular activities designed for students and for teachers. As an example can be cited the website of the UN www.un.org/Pubs/CyberSchoolBus, where one can find educational material for students on health, the environment, a variety of interactive games, maps, databases, quizzes. Such open and available resources become interesting and a new source of information in the educational system, and materials can be used by representatives of different countries irrespective of their level of development and location [5] (UN project on global education and teaching of "Cyberschoolbus" - www.un. org / Pubs / CyberSchoolBus).

The possibility of collective participation in the educational process is created through a variety of interactive systems that allow real-time communication, including e-mail, video conferences and forums. An interesting experience of foreign 
teachers is the use of so-called "electronic class blackboards" www.sisweb.com / math / whiteboard /, newsgroups (www.peg.apc.org/ iearn/works.htm), conferences on the use of computers (www. ascusc.org/jcmc), special programs, such as, Collaborative and Multimedia Interactive learning Environment - General and multimedia learning environment (www.cc.gatech.edu/gvu/ edtech / CaMILE) and The Knowledge Integration Environment (Integrated information Environment ) (www.kie.berkeley.edu/KIE). All these and other resources can be an interesting source of information for the Azerbaijani teachers.

Other facilities include a variety of domains for different users, applications that are called Hallucinations and which are a resource with a virtual environment and text mode where members not only can communicate with each other, and jointly create a single virtual environment. Such information and communication tools allow people at a great distance from each other to become members of the so-called "virtual communities" - groups of pupils who are united by common aims and not on a territorial basis or age from around the world. For these communities there are no barriers of time, distance, age, abilities, cultural and social status. Virtual communication allows them to choose a convenient time, place and pace of material learning. There is a positive experience of so-called virtual design studios, known since 1993 as an example of collaboration between students-architecture groupsarch.hku.hk/projects/vds/. These resources allow communicating professionals (students, teachers) from all over the world who are working on different projects, using computer-aided design system, email, video conferencing, etc. to discuss and evaluate the quality of own designs and projects.

An interesting source of information and tool for creating online communities in the school system is E.D.Patarakin's recent publication "Social services of online communities to help the teacher, 2006", in which the author considers the mechanisms for creating online communities of schoolchildren, the so-called pedagogic communities, as well as providing information on existing networks and resources that can be used by both teachers and students in their daily training and work [6].

It should be pointed out that today in Azerbaijan also started work on the application of computer technology in the educational process. In this respect, there is an interesting experience in the world-famous INTEL Corporation, which considerably invests education on a global scale and operates in 48 countries. In particular, educational programs and INTEL projects are aimed at the development of access to IT and a substantial part of the application of ICT in the learning process. INTEL assigns a special role to teacher's training. According to Head of the INTEL Corporation Board of Directors Craig Barrett, "We need to give students and pupils all the necessary skills to build a successful career in the future.

First of all, we need to provide the teachers with this knowledge, so that they can share their experience with students, in order the first impulse for future changes in the approaches and methods of teaching come from them. Technologies allow teachers easily to share achievements and experiences around the world. With the help of technologies, one can change the methods and approaches in educational practice, and it will allow teachers to be leaders in their field, in education" (Craig Barrett: Russia needs digital transformation http://www.computerra.ru/focus/34370/ [7.]).

Today INTEL has 7 international educational initiatives, the largest of which - INTEL $\AA$ Education for the future. The program covers 37 countries (among them - 10 EU countries). For the 5 years of implementation of the Program over 3 million teachers were trained and more than 21000 thousand of them in Azerbaijan. This program includes the world experience of the effective use of ICT in education. In each country, it adapts to the state standards, provides the latest educational technology and enriched with national experience, which becomes the property of the other participating countries. The program is universal and suitable for training teachers of any specialty who work with children of all ages, it can be used in class-lesson system and during extracurricular time. Results of the monitoring of implementation, compulsory in each country indicate that $90 \%$ of respondents consider it to be an innovative, efficient, and recommend to their colleagues.

An important factor for the application of computer technology in the educational process is the achievement of a certain level of information knowledge by pupils. This concept is related to the fact that most of the institutions implementing distance learning in the education system require an appropriate level of qualification of pupils and apply appropriate standards. For example, American pedagogues have developed a series of standards for precollege training on information and technical knowledge of senior high school pupils - National Educational Technology Standards (National Educational Technology Standards, NRTS cnets.iste.org) [8]. However, EU countries have already in early 2000 implemented a compulsory certification of computer knowledge for the graduates of secondary schools.

As already noted in the conditions of global information of a society and all spheres of life the question of effectiveness of the use of informationcommunication technologies in the sphere of education becomes important. The importance and development of distance learning has been much more growing over the last decades. 
Distance learning is a form of education, equivalent to full-time, evening, extramural and external ones, implemented mainly by distance learning technologies.

Distance learning technologies consist of pedagogical and information technologies of distance learning [12].

Pedagogical technology of distance learning is a technology of indirect active communication of teachers with students through using telecommunication means and methodologies of individual work on the subjects of training on a structured learning material presented in the electronic form.

Information technologies of distance learning is a technology of creation, transmission and maintenance of teaching materials, the organization and conducting of educational process of distance learning using telecommunication facilities [17].

In the existing information education systems (IES) the main components are: electronic library, electronic testing system and the electronic dean's office. The experience of implementation of IES proves the special role of training network teachers to teach by Internet-technology means. The main structural teaching element responsible for educational and methodological support of an open teaching process in IES is a virtual sub-department. Based on the analysis of existing and proven models of virtual sub-departments this looks optimally so: virtual sub-department $=$ Intranet / Internet + teaching technology + relevant infrastructure.

Analysis of wide range of existing software pedagogical means allow making an overall assessment of current progresses in the development of electronic means of teaching in Azerbaijan. Let's compare the results achieved in this area in leading countries, such as Russia. These assessments allow us to make the following conclusion: the current state of computerization of schools and the Internet network in the entire territory of Azerbaijan (in near future) raises the problem of teachers' provision with national digital educational resources for profile teaching of physics.

The analysis of the implementation of various forms of online learning in the educational process and its results showed that the effectiveness of educational objectives can be achieved by the simultaneous use of several forms, in this the dominant contribution of a particular form depends on the specificity of discipline. Complex scientific and methodical analysis of organizational forms for conducting educational process on the network technology of teaching proves that the use of specific forms (e-lectures, online seminar, econsultation, virtual practical and laboratory classes, computer control of knowledge) becomes effective only after the preliminary detailed special training of pupils: conduction of instructive and pilot teachings, additional training on issues for mastering forms of communication through the Internet, developing of a system of incentives for attendance e-learning course.

The results of the research of the studying the experience on the implementation of electronic learning systems showed that though the theoretical and practical basis of learning on physics by means of Internet technologies has methodologically certain apparatus are in the shaping stage. In this regard, there arises a problem of theoretical substantiation and development of didactic approaches to the organization of profile teaching of senior class pupils in the information-educational environment on the Internet.

The level of the problem studying.

Today much prominence is given to the development and implementation of information technologies. Thus, information technologies in the preparation of the teachers of physics was considered by A.I.Bugayev, S.P.Velichko, S.M.Gaiduk, V.G.Gritsenko, I.M.Pustynnikova, A.Doshich, A.Zhelyuk, A.Leshynski V.I. Sumskiy, L.Konoshevsky, Y.A.Jhuk and other organizations of independent work of pupils and physical experiment with the use of modern information technologies by G.Tychuk, A.Martyniuk and many other researcherscientists.

The presentation of the material.

Under the application of new information technologies usually is understood the use of computers in all spheres of human activity. An essential feature of the new teaching information technologies is to focus on an individual approach of the pupils' or the student's training.

The basis for the global information of society is a process of informatization of education. At the same time, it must take the lead over the informatization of other areas of public activity, since namely here the social, psychological, general cultural and professional precondition for informatization of society is formed [16].

However, a common view on application of new information technologies in the field of education has not been formed so far, which can be explained by the lack of sufficiently deep methodological basis for computer-based training. The main burden of computerization of education lies on the teachers of computer science and computer engineering.

Teachers of school subjects usually not ready to use computers in teaching, because they have neither methods for the development of computer technology, nor methods for their use. For the use of computers not only in computer science lessons it is necessary to prepare teachers of specific subjects, which have methods of development and use of computer technology. 
V.Gritsenko showed that the increase of efficiency of educational process can promote the use of new information technologies of teaching [2]. Effective teaching of physics is possible only with the application of ICT elements on these stages of learning when teaching material does not allow the full use of traditional methodology. In particular, the following main trends of use of computer technology on teaching physics, which, fill up the traditional one can be distinguished:

- Visibility of physical objects (phenomena, processes) in the form of demonstrations, and in the form of operating environments, designed for individual use;

- Maintenance of the demonstrative and frontal experiment by means of data acquisition and processing of measurements of the physical quantities (spreadsheets, etc.);

- Consolidation of the educational material and control over its learning;

- Creating opportunities for prompt and easy access to information about the object of study (teaching environment, the hypertext systems).

V.G.Gritsenko identifies two main approaches to computer modeling of physical processes: deterministic (natural, assumed) stochastic (random, unpredictable in advance). In his research, he reveals the essence of each method of modeling and analyzes possible points of contact, in particular, as an example the model of Brownian dynamics [14].

The intensification of the process of learning and its individualization based on the use of new information technologies of teaching helps to improve the professional training of pupils, formation of abilities and skills of computer modeling and their successful use both in educational and research activities.

Now there are a significant number of different computerized training products, such as "The kinematics and dynamics of a point", "Problems on physics for computer", "Physics and Computer" [16]. However, their use in the teaching of physics in modern schools is somewhat problematic, since they focus on the outdated fleet. There are also modern computerized designs for the electronic computers, such as "Physics in Pictures", "Virtual Physics", various "tutors" on physics, chemistry, mathematics, biology, collections of problems and training aids for pupils and students $[13,14]$ recorded on CD.

The most successful are the products that can be used in the study of physics.

These are so-called interactive electronic encyclopedia on the history of technology, astronomy, outer space [17], products Walk and Talk from Poly Vision ${ }^{\circledR}$, which offer the use of interactive technologies for the use of computer in lecture, practical and seminar classes. Walk and Talk are the interactive distance control systems, which are connected to the computer, as well as "L-micro", "Kvazar Micro" of PPM production [18;19].

The concept of the application of electronic computers in the educational process of modern school must comply with the following provisions.

1. To have the required software which does not substitute lecturer at the lecture, but must accompany his (her) narration, that is, to be a software tool that can simulate physical processes, device for performing calculations (particularly complex and bulky).

2. Computers used in teaching laboratories on physics should be available to all, because through them is prepared for the laboratory practical work, calculation and registration of data, etc.

3. Computer complex must comply with ergonomic and sanitary-hygienic requirements. Equipment and organization of the workplace with a PC must ensure that the construction of all the elements of the workplace and their mutual arrangement meets ergonomic requirements with regard to the feature and specifics of working activity. In order to ensure the protection and promotion of normalized levels of computer radiation it should be applied screen arrangement filters, local color filters (individual protective shield for eyes) and other protective facilities that have passed testing in accredited laboratories and have an annual hygienic health certificate.

When a working place equipped with laser printer PC the parameters of the laser radiation must meet the requirements of SanPiNM 5804-91.

4. Computers must record the results of students' work in the electronic version. This allows the teacher to assess the work of each pupil or student in class during the semester or school year.

5. The software, which computer serves lectures, laboratory and practical classes with, should be clear for the teacher and for the pupil, easy and understandable to use.

The work of modern computer and its basic hardware/ service tool is inextricably linked to the software, which is part of the electronic computer. Software is a set of software tools that allow using the potential of the computing system in a convenient way. Depending on which means referred to, programmers use English terms for apparatus and program - Нагdware, Software (word for word: hard set, soft set).

Prior to the acquisition of calculating technology, most users mistakenly believed that with the advent of Нагdwaгe (service tools) their problems associated with the operation of the electronic computer will be resolved, but after that there arises a need in the acquisition and application of Software (program support). The experience in use of computer technology in developed countries shows that the money spent on the acquisition of 
software is 5 - 10 times higher than the cost of the electronic computer itself [15].

The evolution of computing technology is impossible without the development of software. With improvement of computer technology and expansion of spheres of its use appeared packages of applied programs, designed for solving a wide range of tasks: running of the technological process, database systems, information, scientific, educational and other activities [19;20].

In the operation process of computer equipment in a school course of physics on the basis of the software existing and produced by its own forces, as well as analysis of its creation methods described in the scientific, educational and methodical and popular domestic and foreign literature, arose a number of approaches and methods of use of software in educational process for specific types of lessons.

Among the considerable amount of existing software are considered those that can be used in the study of physics and included in the set of educational software (PPM) [18]. PPM is software training implemented in terms of a computer application, arranges teachers' and students' activities aimed at the intensification of the educational process.

In accordance with the type of lesson and its objectives a particular type of software or their combination is used. Classification of educational applied programs for lessons of physics with its types allows the teacher to define clearly the purpose of the lesson and methods to achieve it through using computers, as well as clear and specific motivation of the object activity with the creation of new PPM by teachers and specialists on computer means $[13,14$, 18-20].

Depending on the goals and tasks which are set by using computer technology in the school physics course, the following five types of educational software applied programs can be defined:

Informational - these are programs that bear definite theoretical information of the general plan, main ideas, definitions, concepts, laws and mathematical apparatus necessary to familiarize with the teaching material, and to describe the characteristics of a physical phenomenon or object that is being studied.

Demonstration and modeling is a program that visually reflect the physical phenomena, laws, principles, concepts, interaction of the material world bodies, illustrate and distinguish the main characteristics, features and nuances of objects' behavior, and are studied with the use of graphics, audio and other means for output of computer information.

Calculation is a program that uses the calculating power of computer technology and designed to provide the needs of the mathematical apparatus, which describes physical objects, phenomena and laws of the material world.

Experimental-research programs are the programs intended to ensure the operation of computing technology with external devices, sensors and transformers which transmit information on the investigated physical quantities, phenomenon, objects for processing in a computer, and send the results of their processing to the output device.

Controllers are the programs designed to examine, control, testing of knowledge, ability and skills acquired in the course of mastering a particular volume of educational information. There is no objection that can be used PPM, which combine two or more types of programs in it: informational and controlling, informational and demo, calculation and control, etc. By combining various types of programs, the teacher can choose their varieties depending on the topic, goals and type of the lesson. It should also be remembered that the use of computers (electronic calculation device) cannot be considered effective in every lesson after certain limitations of educational-methodical and sanitaryhygienic plan.

It is known that the course of physics in secondary and higher education institutions includes sections, study and understanding that need advanced creative thinking, the ability to analyze and compare. First of all, we are talking about such sections as "Molecular Physics", "Electrodynamics", "Nuclear Physics" and "Optics".

It should be noted that the secondary school pupils and high school students, first-year students, especially students of nonphysical specialties, do not possess the necessary skills of thinking for deeper understanding the phenomena, processes described in these sections. In such cases means of modern teaching come to help, and first of all - the PC. Such lessons arise real interest of pupils/students, makes all, even poorly trained children to work [25]. At the same time the quality of knowledge significantly increases.

Many phenomena cannot be demonstrated in terms of school physical laboratory. This, for example, the phenomena of the micro world, or processes that occur quickly, experiments with devices that do not exist in the physical laboratory. Children have difficulties, because they are not able to imagine these phenomena, but the computer can create models of phenomena, which will help to solve this problem.

Computer modeling allows you to create a lively, visual and dynamic picture of physical experience or phenomenon on the computer screen, and opens opportunities for teachers to improve lessons.

It should be noted that under the computer models we mean computer programs, imitating 


\begin{tabular}{|c|c|c|c|c|c|c|}
\hline Impact Factor: & $\begin{array}{l}\text { ISRA (India) } \\
\text { ISI (Dubai, UAF } \\
\text { GIF (Australia) } \\
\text { JIF }\end{array}$ & $\begin{array}{l}=1.344 \\
=0.829 \\
=0.564 \\
=1.500\end{array}$ & $\begin{array}{l}\text { SIS (USA) } \\
\text { PИНЦ (Russia) } \\
\text { ESJI (KZ) } \\
\text { SJIF (Morocco) }\end{array}$ & $\begin{array}{l}=0.912 \\
=0.179 \\
=1.042 \\
=2.031\end{array}$ & $\begin{array}{l}\text { ICV (Poland) } \\
\text { PIF (India) } \\
\text { IBI (India) }\end{array}$ & $\begin{array}{l}=6.630 \\
=1.940 \\
=4.260\end{array}$ \\
\hline
\end{tabular}

physical experiments, phenomena or idealized model situations [28].

They easily fit in a traditional lesson.

Computer also enhances and stimulates interest in learning, livens up mental activity and the efficiency of new material acquisition, helps students and pupils who miss classes due to illness, and promotes students' self-reliance [30].

Summary. By analyzing the main trends and approaches to the implementation of computer technologies in the school system, it should be admitted that school education has significantly expanded the range of technologies related to computer and global information networks in recent years. The activities of international organizations, specifically related to training programs for teachers, and large industrial corporations (among them INTEL), which direct the effort, not only to work with pupils, but also to teachers' training, the creation of opportunities for gaining the necessary habits and competencies is important.

Modernity requires teachers the ability to combine organically traditional teaching influences with the active and free use of ICT. The implementation of ICT tools in the educational process, training with computer support, the use of multimedia educational software is often used by teachers to generate pupils' interest in the process of acquiring knowledge.

All of the above noted shows that the implementation of ICT in the educational process, training with computer support, the use of multimedia educational software is often used by teachers to generate pupils' interest in the process of acquiring knowledge and the implementation of modern innovative technologies and teaching methods in education increases the efficiency, opens up new opportunities for professional development of teaching staff.

\section{Summary}

Modeling of various phenomena in no way replaces the real experiences, and together with them will allow explaining the physical laws at a high level.
Information technology is a type of advanced educational (pedagogical) technologies that contribute to the improvement and the development of the educational process and on the whole, the secondary and higher education system.

It should not simply to rework summaries of lessons, textbooks, manuals from paper into an electronic version, but to develop methods and forms of integrated teaching and to train teachers from the first steps of the relevant higher education.

By analyzing the main trends and approaches to the implementation of computer technology in the school system, it should be admitted that in recent years, school education significantly expands the range of technologies related to computer and global information networks. It is important activities of international organizations, specifically related to training programs for teachers, and large industrial corporations (among them - INTEL), which direct the effort, not only to work with the students, but also on teacher training, the creation of opportunities for gaining the necessary habits and competencies.

All these and other aspects are most relevant to the educational community of Azerbaijan. Development of the information educational environment today requires the mastery of modern ICT by young generation and the ability to apply them in learning and everyday life. So, for the countries of the European Union and other economically developed countries in the world computer technology, the development of distance learning, the development of open education institutions are the most important tasks of today's government programs. Azerbaijan also proclaims important priority and strategy course to improve the quality of education and, above all, the effective implementation of information and communication technologies in the educational field, and the experience of foreign colleagues can be an interesting source of educational practice and the exchange of information, the possibility of integration of Azerbaijani teachers to the modern world technologies and educational processes. It should be remembered that the primary school in many European countries differs for age limit and pupils must reach 12 years [2].

\section{References:}

1. (2004) Key Data on Information and Communication Technology in Schools in Europe. - 2004 Edition. - Eurydice / The information network on Education in Europe. pp.3.
2. (2016) The UNESCO World Report on Communication and Information in 1999-2000 -Available: http://www.polpred.com/free/unesco/2.htm (Accessed: 10.03.2016). 


\begin{tabular}{|c|c|c|c|c|c|c|}
\hline Impact Factor: & $\begin{array}{l}\text { ISRA (India) } \\
\text { ISI (Dubai, UAE } \\
\text { GIF (Australia) } \\
\text { JIF }\end{array}$ & $\begin{array}{r}=1.344 \\
=0.829 \\
=0.564 \\
=1.500\end{array}$ & $\begin{array}{l}\text { SIS (USA) } \\
\text { PИНЦ (Russia) } \\
\text { ESJI (KZ) } \\
\text { SJIF (Morocco) }\end{array}$ & $\begin{array}{l}=0.912 \\
=0.179 \\
=1.042 \\
=2.031\end{array}$ & $\begin{array}{l}\text { ICV (Poland) } \\
\text { PIF (India) } \\
\text { IBI (India) }\end{array}$ & $\begin{array}{l}=6.630 \\
=1.940 \\
=4.260\end{array}$ \\
\hline
\end{tabular}

3. (2016) North Carolina State University Available: $\quad$ www.2.ncsu.edu/oit/nsdsplit.htm (Accessed: 10.03.2016).

4. (2016) Ontario Institute for Studies in Education (Ontario Institute for Studies in Education) Available:

www.csile.oise.utoronto.ca/intro.html

(Accessed: 10.03.2016).

5. (2016) UN Project on Global learning and teaching "Cyberschoolbus" - Available: www.un.org/Pubs/CyberSchoolBus (Accessed: 10.03.2016).

6. Patarakin ED (2006) Social services of online communities to assist the teacher. Vladivostok. - 2006. - 34 p.

7. Craig Barrett (2016) Russia needs the digital transformation. Available: http://www.computerra.ru/focus/34370/ (Accessed: 10.03.2016).

8. (2016) National educational technology standards (National Educational Technology Standards, NRTS) Available: www.cnets.iste.org . (Accessed: 10.03.2016).

9. Isayev DA (2004) Computer modeling of curriculum on physics for secondary educational institutions based on personified knowledge. Diss ... Doc. Ped. Sciences. Moscow: 2004, 356 p.

10. Ismayilov IN (1980) Problems of complex use of technical means and programmed materials to enhance the effectiveness of learning physics in high school: Diss ... PhD in Pedagogic. Baku, 1980, $177 \mathrm{p}$.

11. Ismayilov IN (2009) The use of new information technologies in the effective organization of a demonstration experiment in physics.// New technologies in education. Voronezh State Pedagogical University, 2009, №1, pp.14-19.

12. Abbasov AK (2002) Pedagogical technologies and innovations in the educational activity of pupils // School Technology 2002, №5, pp. 1826.

13. Gilbukh YZ (1993) Teacher and the school psychological service. - Kiev: Institute of Psychology of the NAS of the Ukraine, 1993. 142p.

14. Gritsenko VG, Vlasenko VM, Vlasenko AV (2006) Improving the objectivity and quality of students' knowledge control of the Physics Department by means of new information technologies // Vestnik of Cherkassy University. Issue 93. Series: pedagogical sciences.: Collection. - Cherkassy: CSU, 2006. p. 40-44.

15. Kondratiev A (2001) Didactic aspects of distance learning of physics at school / A.S. Kondratiev, V.V. Laptev, A.I. Khodanovich. SPb.:, RCPO, 2001. - 27 p.
16. Chefranova AA (2005) Distance learning of physics at school and university. Theoretical aspects: Monograph / A. Chefranova. Moscow: Prometheus, 2005. - 332 p.

17. Borisenok SV (2009) Problems of quality control of knowledge in the course of methods of teaching of physics at the present stage of development of the higher levels of education [electronic resource] / S. B.Borisenok, A.M. Karaseva // Modern problems of science and education. - 2009. - №2. - Available: http://www.scienceeducation.ru/download/2009/02/2009_02_07.pd f (Accessed: 10.03.2016).

18. Tikhomirov YV (2003) Computer control of knowledge in distance learning on the course of physics / Y.V. Tikhomirov // Computer Tools in Education. - 2003. - № 4. - pp.19-25.

19. Voronkin AS (2012) Practice of the open distance learning course "Introduction in the physics of acoustics."/ A.S.Voronkin//.Theory and methods for teaching of mathematics, physics and information science: collection of scientific works. - Edition X: in 3 volumesKrivoy Rog:.NMetAU Publishing Department, 2012.- v. 2: Theory and methods for teaching of physics. - pp. 44-53.

20. Voronkin AS (2012) Preliminary results of the author's open distance learning course "Introduction in the physics of acoustics. 2011" [Electronic resource] / A.S. Voronkin. Lugansk: Information and educational portal "The technology of distance learning." Available: http://tdo.at.ua/news/zvuk/2012-0107-51. (Accessed: 10.03.2016).

21. Feynman R (2001) What Do You Care What Other People Think? / R.Feynman. - Izhevsk: Regular and Chaotic Dynamics, 2001. - 208 p.

22. Turchin VF (2000) Phenomenon of science: The cybernetic approach to evolution / V.F. Turchin. - Moscow: ETS, 2000. - 368 p.

23. Voronkin AS (2012) Introduction in the physics of acoustics. Teaching aid / A.S.Voronkin. Lugansk: LSICI Publishing house, 2012. - 96 p.

24. (2016) Virtual school of scientific and technical creativity of informational-educational portal "Distance Education Technologies" [Electronic resource] / Active group "V Kontakte (I contact)".

http://vk.com/club36640106

Available: 10.03.2016).

25. Shukurov RY (1989) The use of computer technology as a means of activization of informative activity of pupils at the lessons of physics. Diss ... cand. Ped. Science. Baku: 1989, $153 \mathrm{p}$.

26. Moroz IV (2005) Pedagogical conditions of the implementation of credit-modular system for the organization of educational process: 
\begin{tabular}{l|lrl|l|ll} 
& ISRA (India) & $=\mathbf{1 . 3 4 4}$ & SIS (USA) & $=\mathbf{0 . 9 1 2}$ & ICV (Poland) & $=\mathbf{6 . 6 3 0}$ \\
Impact Factor: & ISI (Dubai, UAE) $=\mathbf{0 . 8 2 9}$ & PUHL (Russia) $=\mathbf{0 . 1 7 9}$ & PIF (India) & $=\mathbf{1 . 9 4 0}$ \\
& GIF (Australia) & $\mathbf{0 . 5 6 4}$ & ESJI (KZ) & $=\mathbf{1 . 0 4 2}$ & IBI (India) & $=\mathbf{4 . 2 6 0}$ \\
& JIF & $\mathbf{1 . 5 0 0}$ & SJIF (Morocco) & $=\mathbf{2 . 0 3 1}$ & & \\
\hline
\end{tabular}

Monograph. - K.: Education of the Ukraine, 2005. - $196 \mathrm{p}$.

27. Babiy II (2004) Formation of quality assurance in higher education: The report on the scientific and practical seminar "Credit-modular system for the organization of educational process", July 1-2, 2004, Ternopil. Available: Http://www.tspu.edu.ua/php/kms/6/ (Accessed: 16.10.2004)

28. Krasilnikova VA (2002) Methodology for creating a single information-educational environment of the university district // Vestnik of OSU, 2002. -№2. - pp.105-110.

29. Obraztsov PI (2001) Information-technological support of educational process in higher school // Higher education in Russia, 2001. - № 6. p. 16-22.

30. Obraztsov PI (2000) Psycho-pedagogical aspects of development and application of information technologies of teaching at university / Orel State Technical University. Orel, 2000. - 145 p. 